\title{
Analyzing the Status of Iran's Textile Industry in Comparison with Industries listed in Tehran Stock Exchange
}

\author{
Ahmad Moradi \\ Dept. of Management, University of Isfahan \\ E-mail: moradiiran@yahoo.com \\ Ahmad Abedini \\ Dept. of Management, University of Isfahan \\ E-mail: ahmadabedini66@yahoo.com \\ Javad Khazaei Pool (Corresponding author) \\ Dept. of Management, University of Isfahan \\ E-mail: khazaei110@gmail.com
}

Accepted: June 17, 2012 Published: July 13, 2012

Doi:10.5296/ijhrs.v2i3.2099

URL: http://dx.doi.org/10.5296/ijhrs.v2i3.2099

\begin{abstract}
Textile industry has been influenced by the globalization process more than any industry in the world. Given that a high volume of the country's industry is at disposal of small and medium industries it seems that paying attention to textile industries and improving their status could be a useful strategy for economic development of the country. Objective of the present paper is to evaluate textile industry in comparison with industries listed in Tehran Stock Exchange. Therefore, dividend, final price of each section, percentage of price change, percentage of profit to price, total return, percentage of increasing of dividend per share have been evaluated for certain time periods in comparison with the selected industries using a combination of factorial analysis and numerical taxonomy methods based on a set of selected indexes such as those related to number of stocks traded. According to results of the present survey textile industry has been dropped from rank 9 in 2009 to rank 8 in 2008 in two time periods under study. This shows there is a basic weakness in this industry and necessity of a new and innovative strategy seems essential.
\end{abstract}


Keywords: dividend, numerical taxonomy, stock exchange, textile industry

\section{Introduction}

Textile industry is one of the most complicated manufacturing industries due to the sparse and heterogeneous small and medium companies under its dominance (Hasanbeigi et al, 2012). Given to old antiquity of textile industry in Iran and investments made on purchasing the machineries offering various and customized products and having access to the external and even internal markets are not still possible. Unfortunately, not only appropriate assessment models are not used in Iran's textile industry but also undesirable performance assessment is obtained through inefficient mechanisms which are designed by the related authorities. Consequently real results of assessment are just deviated. Its consequence would be lack of confidence in the concept of performance assessment in the industry. It is obvious that determining indexes related to performance of the country's textile industry is essential given to rapid changes under conditions where each index has its special degree of importance. Given to the weakness of this industry in total performance assessment which has been led to reworking, deficiency in assessment system and wasting of organizational resources (in all financial aspects, human force and etc) there is no alternative except designing and compiling a total performance assessment system. Generally, it is intended in this paper to represent measurable, efficient and effective indexes for performance assessment in the country's textile industry, having access to total performance assessment of textile factories and comparing the performance of this industry with other industries listed in the stock exchange. The existing indexes in the stock exchange have been used to evaluate this industry.

Today stock exchange as a very important tool in the capital market plays a special role in economic growth and provides the ground for economic prosperity through pricing, decreasing risk, equipping resources and optimal allocation of capital (Amiri et al, 2008). Stock exchange means an organized and formal capital market in which buying and selling of companies' stock or public securities or securities of reliable private institutions are conducted under special regulations. The important feature of stock exchange from one side is to collect savings and liquidity of the private sector to finance long-term investment projects. From the other side it is a formal and secure reference that holders of stagnant savings could search a relatively appropriate and secure place for investment and invest their excessive funds in corporations or enjoy a certain and guaranteed profit by purchasing governmental securities or that of reliable companies (Javadi,1995 and Khodabakhsh, 2004). Index is a tool to measure and compare phenomena which have specific nature and feature. Thus it is possible to study the accomplished changes in certain variables during a period based on index (Ghafari, 204). Stock exchange index has a wide application both from investors' viewpoint to invest in specific stock and as an economic index in the society in macro economy's viewpoint. The term index means chart, representative, demonstrator and indicator. In applied terms index is a quantity which represents several homogenous variables (Amiri et al, 2009). From the other side, investment in each kind of activity in the modern world needs to have sufficient 
information and the related proficiency. Having sufficient information and the related proficiency for investment in the stock exchange is more important given to the existing risk in this market, since it has a very high volume and too diversified information in addition to the point that it is a specialized market. Thus the investor should have sufficient time and precision along with having the related proficiency to analyze the above information (Hoshmand and Khodadost, 2008). A large portion of information related to companies in Tehran stock exchange has been summarized in the form of measurable indexes in various groups of superior industries in the present paper and the existing superior industries have been ranked based on their degree of indexes using numerical taxonomy analysis method. The time period includes two one-year periods from the beginning of the year 2008 until September 2009. Factorial analysis of indexes, identifying homogenous industries and finally ranking of industries are used to conduct analyses related to evaluation of textile industry in comparison with industries listed in Tehran stock exchange. Factorial analysis is used to identify indexes dependent on each other and determining homogenous industries as well as their ranking are conducted through numerical taxonomy analysis.

\section{Literature review}

\subsection{Stock exchange markets}

Stock exchange market is divided into primary market and secondary market in terms of issuance priority and access to securities (Davani, 2004):

Primary market

It is said to a market in which new securities are issued for the first time by an organization or company.

Secondary market and the stock exchange

It is said to arrangements through which sellers and buyers can exchange securities that their supply period in the primary market has been finished through a common method and acceptable prices for both parties.

\section{2-2 Comparing indirect sector of the secondary market with coherent sector of the stock market}

Stock exchange in comparison with coherent sector of the secondary market has various advantages that the most important of them are as below:

Existence of a certain place to exchange securities

Facilitating exchange of securities through determining the transaction price of securities and Making investment in securities attractive by maintaining liquidity capability and rapid selling of securities (Jahankhani and Parsaian, 2008)

\subsection{Indexes and analyses used in the stock exchange}

\subsubsection{Applying the price index}

Among the most important applications of stock exchange price index (Davani, 2004) we can refer to the following:

1- Index numbers illustrate general information about the market structure. In fact index shows total status of economy and market like a thermometer. Index reduction is 
usually interpreted as economic stagnation and its increase means economic prosperity.

2- Index is a tool to compare changes of a phenomenon in two different times.

3- It is possible to follow probable changes of prices in the future by studying index numbers and

4- Index is a tool to compare group changes of several phenomena with each other. It is possible to compare different industries with each other using price index.

\subsubsection{Index of fifty companies listed in the stock exchange}

Taking a look at the experience of stock exchanges in different countries reveal that recognizing prominent companies or those having superior status is often based on the below criteria:

Liquidity power of stock means high volume of transactions in the stock exchange, effectiveness degree of the company on the market or its share in the current value of market and status of the company in terms of superiority and financial ratios especially degree of productivity per share.

Recognizing superior companies in Ian's stock exchange is accomplished based on a combination of stock liquidity and effectiveness degree of the company on market in the framework of the following three standards:

1- Amount of stock trading that includes number of the traded stock and its value.

2- Alternation of stock exchange that includes number and times of the trading.

3- Effectiveness standard of the company on the market that includes average number of issued shares and average current value of the company's stock in the period under study (Hoshmand and Khodadost, 2008).

\subsection{Applied methods to analyze status of companies and industries}

Shareholders and analysts analyze the existing data and information from each industry or company through various methods. Three important and applied methods are mentioned briefly below.

\section{Technical or effect.oriented method}

The analyst in this method just considers the price process and its diagram. He doesn't look for the reason of prices' fluctuation and effective factors on it; rather he only examines the effect that is fluctuation of the company's stock prices. Chartists are famous for this reason.

\section{fundamentalist or cause-oriented method}

In this method contrary to the previous method the analyst believes that all external and internal factors of the company are involved in changing its stock price and he predicts the stock price change by analyzing them. These analyses are conducted at three macro, industry and company levels.

\section{Modern theory of MPT}

Analyses in this method are based on risk and return and are used more in investment companies. This is totally mathematical and is complicated to some extent.

\subsection{Factorial analysis}

This method was used for the first time by Charles Spearman. It is applied for comparison, 
thus the intended comparative variables or indexes are collected for each member to be compared and a matrix called primary data matrix is constituted. Then correlation matrix among members is calculated that its product is upper triangular matrix or lower triangular matrix. Some variables in this matrix have a high correlation and create a group. Therefore, at least one group and at most groups equal to the number of variables could be created. The existing variables in each group have a low correlation with variables of other groups. In each of these groups if comparative variables or indexes are recognized and used properly, they have common features which are called common factor in factorial analysis. Thus those common factors would be recognized and omitted. After conducting factorial analysis in this paper using SPSS software it has been determined that three variables are common factors among ten variables under study which must be omitted. Other variables (indexes) that have been studied in the present paper will be mentioned later.

\subsection{Numerical taxonomy}

"Numerical taxonomy" method has been used in the present paper to analyze data that is one of the methods for ranking activities. It is one of the best methods to rank different activities in terms of having similar indexes. This method could divide one set into more or less homogenous subsets and represents a suitable scale to recognize degree of having the intended indexes and economic and social development degree that is utilized to analyze activities.

This method was represented by Adansson in 1763 for the first time and then was developed by polish mathematicians at the beginning of second half of the $20^{\text {th }}$ century. Then it was proposed as a tool to measure and rank development of various nations in UNESCO in 1968. Taxonomy analysis is performed in several steps as below:

Constitution of data matrix, standardization of data matrix, constitution of distance matrix, determining homogenous distances, ranking homogenous activities in terms of indexes under study and calculating degree of homogenous activities

\subsection{Indexes under study}

Indexes that have been studied and analyzed in this paper include seven different indexes which have been selected among ten indexes using factorial analysis. These indexes are as below:

Number of shares traded, dividend, amount of share capital, percentage of change of share price market value, degree of liquidity, final price of each section, percentage of price change, percentage of earning to price $(\mathrm{e} / \mathrm{p})$, percentage of increasing of earning per share and ROE.

\section{Methodology}

Methodology and conducting the related analyses are represented in two sections. First, factorial analysis is conducted about indexes under study to examine indexes have no linear correlation. Then in the second stage numerical taxonomy method is used to analyze data.

Seven different indexes have been studied and analyzed in this paper which have been selected among ten indexes using factorial analysis. They are as below:

1- Number of shares traded, 2- percentage of change of share price market value, 3- final 
price of each section, 4- percentage of price change, 5- percentage of earning to price (e/p) , 6ROE, 7- percentage of increased earning per share.

Textile industry has been compared with superior industries which were selected by opinion poll from experts of financial management and the stock exchange that are as the following: 1- basic Metals, 2- exploiting metal ores, 3- automobile and building parts, 4- cement, lime and plaster, 5- chemical products, 6- oil products, 7- technical and engineering services, 8industrial multidisciplinary companies.

\section{Findings}

Ranking of textile industry in comparison with superior industries of Tehran stock exchange was conducted in 2008 and 2009 using taxonomy analysis that the results are illustrated in tables 1 to 8 .

Table 1. matrix of information related to 2008

\begin{tabular}{|c|c|c|c|c|c|c|c|}
\hline Industry's Name & $\begin{array}{c}\text { Number of Shares } \\
\text { Traded }\end{array}$ & M.V & $\begin{array}{c}\text { Price of Each } \\
\text { Section }\end{array}$ & Price Change & $\mathrm{E} / \mathrm{P}$ & EPS & ROE \\
\hline Basic Metals & $9,177,000,000$ & -0.455 & $3,247.5$ & -0.458 & 0.389 & 1,263 & 0.349 \\
\hline Exploiting Metal Ores & $1,307,000,000$ & -0.511 & $1,205.8$ & -0.524 & 0.28 & 338 & 0.676 \\
\hline $\begin{array}{l}\text { Automobile and } \\
\text { Building Parts }\end{array}$ & $2,671,000,000$ & -0.192 & $2,625.7$ & -0.2 & 0.4484 & 1,177 & 0.319 \\
\hline $\begin{array}{c}\text { Cement, Lime and } \\
\text { Plaster }\end{array}$ & $496,000,000$ & 0.095 & 158.5 & -0.125 & 0.19 & 30 & 0.328 \\
\hline Textile & $1,000,000$ & -0.169 & 209.0 & -0.17 & 0.086 & 18 & 1.034 \\
\hline Chemical Products & $659,000,000$ & -0.474 & 254.7 & -0.462 & 0.37 & 94 & 0.398 \\
\hline Oil Products & $1,302,000,000$ & 3.526 & $21,416.7$ & -0.243 & 0.333 & 7,132 & 0.598 \\
\hline $\begin{array}{c}\text { Technical and } \\
\text { Engineering Services }\end{array}$ & $4,536,000,000$ & -0.223 & 469.9 & -0.231 & 0.2754 & 129 & 0.230 \\
\hline $\begin{array}{c}\text { Industrial } \\
\text { Multidisciplinary } \\
\text { Companies }\end{array}$ & $2,240,000,000$ & -0.0317 & 55.1 & -0.04 & 0.2985 & 16 & 0.275 \\
\hline
\end{tabular}

Table 2. matrix of information related to 2009

\begin{tabular}{|c|c|c|c|c|c|c|c|}
\hline Industry's Name & $\begin{array}{c}\text { Number of Shares } \\
\text { Traded }\end{array}$ & M.V & $\begin{array}{c}\text { Price of Each } \\
\text { Section }\end{array}$ & $\begin{array}{c}\text { Price } \\
\text { Change }\end{array}$ & E/P & EPS & ROE \\
\hline Basic Metals & $3,225,000,000$ & 0.6600 & 6672.1 & 1.055 & 0.147 & 980.7987 & 31.43 \\
\hline Exploiting Metal Ores & $907,000,000$ & 0.6700 & 2406.7 & 0.996 & 0.10277 & 247.336559 & 29.63 \\
\hline $\begin{array}{c}\text { Automobile and } \\
\text { Building Parts }\end{array}$ & $3,800,000,000$ & 0.0500 & 3464.7 & 0.32 & 0.346 & 1198.7862 & 28.14 \\
\hline $\begin{array}{c}\text { Cement, Lime and } \\
\text { Plaster }\end{array}$ & $875,000,000$ & -0.1100 & 163.4 & 0.031 & 0.2288 & 37.38592 & 9.3 \\
\hline
\end{tabular}



2012, Vol. 2, No. 3

\begin{tabular}{|c|c|c|c|c|c|c|c|}
\hline Textile & $3,000,000$ & -0.1871 & 175.2 & -0.162 & 0.0108 & 1.89216 & 9.3 \\
\hline Chemical Products & $606,000,000$ & 0.4500 & 457.7 & 0.797 & 0.1644 & 75.24588 & 31.05 \\
\hline Oil Products & $2,249,000,000$ & 0.0600 & 26167.6 & 0.222 & 0.2597 & 6795.72572 & 30.14 \\
\hline $\begin{array}{c}\text { Technical and } \\
\text { Engineering Services }\end{array}$ & $2,440,000,000$ & 1.0900 & 127 & 1.295 & 0.13 & 16.445 & 32.5 \\
\hline $\begin{array}{c}\text { Industrial } \\
\text { Multidisciplinary } \\
\text { Companies }\end{array}$ & $1,695,000,000$ & 0.5200 & 799 & 0.7 & 0.1758 & 140.42904 & 19.06 \\
\hline
\end{tabular}

Table 3. standard matrix related to 2008

\begin{tabular}{|c|c|c|c|c|c|c|c|}
\hline Industry's Name & $\begin{array}{c}\text { Number of } \\
\text { Shares Traded }\end{array}$ & M.V & $\begin{array}{c}\text { Price of Each } \\
\text { Section }\end{array}$ & $\begin{array}{c}\text { Price } \\
\text { Change }\end{array}$ & E/P & EPS & ROE \\
\hline Basic Metals & 2.341 & -0.494 & -0.007 & -1.099 & 0.848 & 0.057 & -0.459 \\
\hline Exploiting Metal Ores & -0.413 & -0.538 & -0.303 & -1.490 & -0.153 & -0.345 & 0.808 \\
\hline $\begin{array}{c}\text { Automobile and Building } \\
\text { Parts }\end{array}$ & 0.064 & -0.287 & -0.097 & 0.430 & 1.394 & 0.019 & -0.573 \\
\hline Cement, Lime and Plaster & -0.697 & -0.062 & -0.455 & 0.875 & -0.980 & -0.479 & -0.538 \\
\hline Textile & -0.870 & -0.269 & -0.447 & 0.608 & -1.936 & -0.484 & 2.190 \\
\hline Chemical Products & -0.640 & -0.509 & -0.441 & -1.123 & 0.674 & -0.451 & -0.269 \\
\hline $\begin{array}{c}\text { Oil Products } \\
\text { Technical and Engineering } \\
\text { Services }\end{array}$ & -0.415 & 2.632 & 2.629 & 0.175 & 0.334 & 2.605 & 0.503 \\
\hline $\begin{array}{c}\text { Industrial Multidisciplinary } \\
\text { Companies }\end{array}$ & -0.717 & -0.312 & -0.410 & 0.246 & -0.196 & -0.436 & -0.918 \\
\hline
\end{tabular}

Table 4. standard matrix related to 2009

\begin{tabular}{|c|c|c|c|c|c|c|c|}
\hline Industry's Name & $\begin{array}{c}\text { Number of } \\
\text { Shares Traded }\end{array}$ & M.V & $\begin{array}{c}\text { Price of } \\
\text { Each } \\
\text { Section }\end{array}$ & $\begin{array}{c}\text { Price } \\
\text { Change }\end{array}$ & E/P & EPS & ROE \\
\hline Basic Metals & 1.155 & 0.712 & 0.259 & 0.938 & -0.279 & -0.034 & 0.731 \\
\hline $\begin{array}{c}\text { Exploiting Metal Ores } \\
\text { Automobile and Building } \\
\text { Parts }\end{array}$ & -0.667 & 0.736 & -0.248 & 0.821 & -0.738 & -0.367 & 0.541 \\
\hline
\end{tabular}




\section{Macrothink $\Lambda$ Institute ${ }^{\mathrm{m}}$}

International Journal of Human Resource Studies

ISSN 2162-3058

2012, Vol. 2, No. 3

\begin{tabular}{|c|c|c|c|c|c|c|c|}
\hline Cement, Lime and Plaster & -0.692 & -1.091 & -0.515 & -1.100 & 0.569 & -0.463 & -1.605 \\
\hline Textile & -1.378 & -1.272 & -0.513 & -1.485 & -1.691 & -0.479 & -1.605 \\
\hline Chemical Products & -0.904 & 0.220 & -0.480 & 0.424 & -0.099 & -0.446 & 0.691 \\
\hline Oil Products & 0.388 & -0.693 & 2.576 & -0.720 & 0.890 & 2.612 & 0.595 \\
\hline $\begin{array}{c}\text { Technical and Engineering } \\
\text { Services }\end{array}$ & 0.538 & 1.719 & -0.519 & 1.416 & -0.455 & -0.472 & 0.844 \\
\hline $\begin{array}{c}\text { Industrial Multidisciplinary } \\
\text { Companies }\end{array}$ & -0.048 & 0.384 & -0.439 & 0.231 & 0.020 & -0.416 & -0.575 \\
\hline
\end{tabular}

Table 5. distance matrix related to 2008

\begin{tabular}{|c|c|c|c|c|c|c|c|c|c|}
\hline Industry's Name & \multicolumn{7}{|c|}{ distance matrix } \\
\hline Basic Metals & 0.000 & 3.255 & 2.808 & 4.141 & 5.341 & 3.066 & 5.798 & 2.487 & 3.663 \\
\hline Exploiting Metal Ores & 3.255 & 0.000 & 2.908 & 2.905 & 3.132 & 1.436 & 5.518 & 2.710 & 3.311 \\
\hline Automobile and Building Parts & 2.808 & 2.908 & 0.000 & 2.616 & 4.473 & 1.977 & 5.021 & 1.847 & 1.805 \\
\hline Cement, Lime and Plaster & 4.141 & 2.905 & 2.616 & 0.000 & 2.916 & 2.646 & 5.445 & 1.794 & 1.293 \\
\hline Textile & 5.341 & 3.132 & 4.473 & 2.916 & 0.000 & 3.996 & 5.984 & 3.917 & 3.693 \\
\hline Chemical Products & 3.066 & 1.436 & 1.977 & 2.646 & 3.996 & 0.000 & 5.574 & 2.221 & 2.709 \\
\hline Oil Products & 5.798 & 5.518 & 5.021 & 5.445 & 5.984 & 5.574 & 0.000 & 5.543 & 5.492 \\
\hline Technical and Engineering Services & 2.487 & 2.710 & 1.847 & 1.794 & 3.917 & 2.221 & 5.543 & 0.000 & 1.425 \\
\hline Industrial Multidisciplinary Companies & 3.663 & 3.311 & 1.805 & 1.293 & 3.693 & 2.709 & 5.492 & 1.425 & 0.000 \\
\hline
\end{tabular}

Table 5. distance matrix related to 2009

\begin{tabular}{|c|c|c|c|c|c|c|c|c|c|}
\hline Industry's Name & \multicolumn{7}{|c|}{ distance matrix } \\
\hline Basic Metals & 0.000 & 1.988 & 2.987 & 4.216 & 4.946 & 2.344 & 4.366 & 1.570 & 2.117 \\
\hline Exploiting Metal Ores & 1.988 & 0.000 & 3.960 & 3.663 & 3.930 & 0.984 & 5.003 & 1.741 & 1.647 \\
\hline Automobile and Building Parts & 2.987 & 3.960 & 0.000 & 3.409 & 5.160 & 3.481 & 4.017 & 4.064 & 2.981 \\
\hline Cement, Lime and Plaster & 4.216 & 3.663 & 3.409 & 0.000 & 2.400 & 3.132 & 5.042 & 4.774 & 2.395 \\
\hline Textile & 4.946 & 3.930 & 5.160 & 2.400 & 0.000 & 3.729 & 5.885 & 5.343 & 3.384 \\
\hline Chemical Products & 2.344 & 0.984 & 3.481 & 3.132 & 3.729 & 0.000 & 4.846 & 2.337 & 1.554 \\
\hline Oil Products & 4.366 & 5.003 & 4.017 & 5.042 & 5.885 & 4.846 & 0.000 & 5.600 & 4.758 \\
\hline Technical and Engineering Services & 1.570 & 1.741 & 4.064 & 4.774 & 5.343 & 2.337 & 5.600 & 0.000 & 2.403 \\
\hline Industrial Multidisciplinary Companies & 2.117 & 1.647 & 2.981 & 2.395 & 3.384 & 1.554 & 4.758 & 2.403 & 0.000 \\
\hline
\end{tabular}

Table 7. final results of taxonomy analysis in 2008

\begin{tabular}{|c|c|c|}
\hline Industry's Name & $\begin{array}{c}\text { Minimum of } \\
\text { each industry }\end{array}$ & Rank \\
\hline Cement, Lime and Plaster & 1.293326267 & 1 \\
\hline $\begin{array}{c}\text { Industrial Multidisciplinary } \\
\text { Companies }\end{array}$ & 1.293326267 & 2 \\
\hline Technical and Engineering Services & 1.425121328 & 3 \\
\hline
\end{tabular}




\begin{tabular}{|c|c|c|}
\hline Exploiting Metal Ores & 1.436164863 & 4 \\
\hline Chemical Products & 1.436164863 & 5 \\
\hline Automobile and Building Parts & 1.804827893 & 6 \\
\hline Basic Metals & 2.487189835 & 7 \\
\hline Textile & 2.915831867 & 8 \\
\hline Oil Products & 5.021101249 & 9 \\
\hline
\end{tabular}

Table 8. final results of taxonomy analysis in 2009

\begin{tabular}{|c|c|c|}
\hline Industry's Name & Minimum of each industry & Rank \\
\hline Oil Products & 3.567834 & 1 \\
\hline Basic Metals & 4.252595 & 2 \\
\hline Automobile and Building Parts & 4.865580 & 3 \\
\hline Technical and Engineering Services & 5.025057 & 4 \\
\hline Industrial Multidisciplinary Companies & 5.413778 & 5 \\
\hline Exploiting Metal Ores & 5.458757 & 6 \\
\hline Chemical Products & 5.638146 & 7 \\
\hline Cement, Lime and Plaster & 6.781965 & 8 \\
\hline Textile & 7.965034 & 9 \\
\hline
\end{tabular}

Results in tables (7) and (8) indicate textile industry has been dropped from rank 8 to rank 9 in 2009. This shows a major weakness in this industry and necessity of a new strategy.

\section{Discussion and conclusion}

Given to the conducted comparison, using tools and indexes of the present paper for companies as well as investors to make more accurate decisions would be too helpful. As a result companies which are in the first rank should compile a suitable strategy to maintain their status, while weaker companies should try to decrease their distance with stronger companies and improve their status in ranking.

As it is observed in table (7) cement, lime and plaster industry and oil products industry have had the best and the worst performance in 2008 respectively. Textile industry in the same year gained rank 8 that if we consider return on equity in this industry, we would see that it has had a good return. This is while it has been dropped to rank 9 in 2009. Also this reduction is true about dividend per share, percentage of dividend per share to price of each share and other indexes except volume of transactions. It must be considered that only price growth index could not be a guide for the shareholder, because one of the major problems of shareholders is to cash the company's stock at any moment and converting it into another property to eliminate predictable risk of the market in this way. But liquidity index of textile industry and number of its transaction days have been very low and its market growth has been slower than other countries. 
To maintain textile industry the manufacturers should have possibilities to be able to produce competitive textiles and continue their survival globally and inside the country in competitive markets in terms of quality, price and process of rapid production. Textile industry in Iran requires a new strategic plan so that it could act in internal and external markets better than its competitors and be a leader in the market. Thus the most important necessary strategies in order to have a successful presence in markets and solve those problems with which the textile industry is faced are recommended below:

1- Continuous improvement of products and production of new models

2- Reinforcement of customers' loyalty to products' brand in B2B and B2C scope

3- Rapid delivery and timely supply of products to customers and attracting their confidence or building confidence in the market especially among distributors

4- Creating variety in models and designs, packaging, production and development of new products in proportion with customers' needs

5- Developing and reinforcing research and development section and attracting competent individuals in this field

6- Export promotion through proficient exporter companies

\section{References}

Amiri, A.P, Amiri,M.P., and Amiri, M.P., (2009), Designing a New Model of Effective Financial Factors on TEPIX with Structural Equation Model and Fuzzy Approach, J Appl Sci, 9(11): 2097-2105.

Davani, G (2004). Stock Exchange, Shares and Shares Assessment.Tehran: Nashr Nakhostin.

Ghaffari, Younes, (2004), Guide to Investing in the stock, Tabriz, Shayesteh publication.

Hasanbeigi, A., Hasanabadi, A., Abdorrazaghi, M.,(2012), Comparison analysis of energy intensity for five major sub-sectors of the Textile Industry in Iran „Journal of Cleaner Production,23(1),186-194.

Hoshmand, M.,Khodadost,H.,( 2008), Ranking of Projected Indacators for Industries Listed in Tehran Stock Exchange, Knowledge and Development, 15(24),183-203.

Jahankhanian, A., parsaian,A., (2008), Investment management and securities valueation, University of Tehran .

Javadi, J., (1995), The effect of macroeconomic variables on the price index - stocks and investors' decision in the Tehran Stock Exchange during the years of 1990-2000, MS Thesis, Tehran: Shahid Beheshti University.

Khodabaksh, A., (2004), buying and selling stocks based on international resolutions, Tehran: Publications chalesh. 